\title{
畜産食品の保存に関する研究（4）
}

\section{$0.5 \mathrm{Mrad}$ の $\gamma$ 線照射による鶏肉の保存効果}

(㕷 利 41 年 3 月 28 日受埋)

木崎卓平* 神谷誠*

Studies on the Preservation of Animal Foods (4)

Preservative Effects of $\gamma$-Ray Irradiation at Levels of $0.5 \mathrm{Mrad}$

Takuhei KIZAKI and Makoto KAMIYA

(Faculty of Agriculture, Meiji University :

5158, Ikuta, Kawasaki)

Ground chickens ( $M$. pectoralis) irradiated by ${ }^{60} \mathrm{Co} \gamma$-ray at levels of 0.5 Mrads were stored at about $25^{\circ} \mathrm{C}$ and about $4^{\circ} \mathrm{C}$. As the criteria for preservative effects of irradiation and chemical or bacteriological changes after irradiation, Sensory test, pH, Resazulin Reduction Test, Volatile Basic Nitrogen, Free-Tyrosine, Bacterial Numbers and detection of diazo reaction positive substances were carried out.

The results were showen in Tables $1 \sim 4$ and Fig. $2 \sim 4$. As the summary, it was found that the storage life of irradiated chickens were extended for more about 2 days compared with control, and the application combined with irradiation and refrigeration was effective certainly without any extensive chemical changes for 20 days.

Determination of Free-Tyr. was seemed to be effective for the method of detecting spoilage of chickens.

(Received March 28, 1966)

\section{I 緒 言}

筆者らはさきに1.0 Mrad 照射により，25保存彩肉の 保存期間を非照射肉に比べ約 1 週間延黄させうること, 照射と冷蔵との併用により, さらに保存効果が面められ ることを確認し報告1)した.引き続き，0.5 Mrads の線量 で照射した場合の鶏肉の保存効果に関し, 実験検討を加 えたので，その結果をここに報告する.

\section{III試料およひ実験方法}

1. 試料

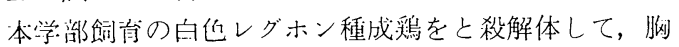

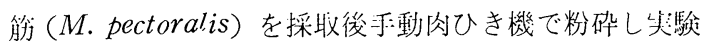
に供した。この一連の操作はできるだけ無菌状態の維持 に努めた。

2. 垁験方法

(1) $\gamma$ 線照射 上茫粉砕試料を, 11 径 $15 \mathrm{~mm}$ 岁さ $50 \mathrm{~m}$ $\mathrm{m}$ の保仔用共せんガラス試験管にそれぞれ約 $10 \mathrm{~g}$ ずつ入 れ, 密せん後照射試料と非照射試料とに区分した。照

* 明治大学農学部 : 神奈川県川崎市生田5158
射区の試料は ${ }^{60} \mathrm{Co}$ 線源の $\gamma$ 線を $0.5 \mathrm{Mrads}\left(0.5 \times 10^{6}\right.$ rads）照射した，照射時の湓度は約 $20^{\circ}$ ，照射時間は 2 時間43分であった。

(2) 保存方法 ガラス弑験管封入試料（照射区. と非照 射区）を䇥温器 $\left(25 \pm 2^{\circ}\right)$ と冷蔵愺 $\left(4 \pm 1^{\circ}\right)$ に分けて保 存する.したがって試料は 4 群となる.と殺解体約 5 〜 6 時間後に最初の分析を行なった。

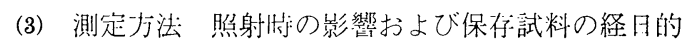
変化を解明するため，つぎの項目について測定を行なっ た。

（i）能検査：試料の形状，におい，丘調等の守能所 見を記録する。

(ii) 水素イオン濃度の測定：WTW 製 $\mathrm{pH}$ メータ 一を州い肉洦接触により直接测足する.

(iii) レサズリン還元試験 $(R R T)^{2)}$ : 試料 $1 \mathrm{~g}$ をレサ ズリン試験管に無菌蒸留水 $10 \mathrm{ml}$ ととに入れ, これに レサズリン溶液 $1 \mathrm{ml}$ を加え密せん後静かに数回転倒し 混利する. 恒温水槽 $\left(35 \sim 37^{\circ}\right)$ に入れ, 一定時間後の呈 
色状況を色調表と比較して判定する.

(iv) 揮発性塩基性窒素 (VBN) の芫量 : Fig. 1 のご とく調製した試料について, 微量拡散法3)により定量す る.

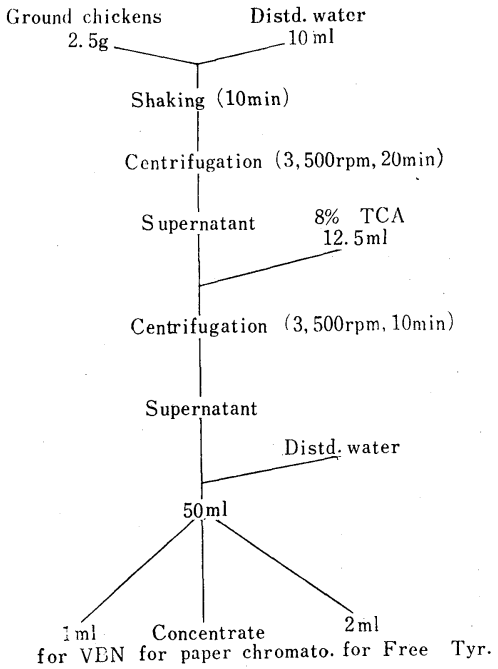

Fig. 1. Sample preparation methods for VBN, Free tyrosine and paper chromatography

（v）遊離チロシンの定量：VBN 定量のための試料 2 $\mathrm{ml}$ を比色試験管にとり, 混合アルカリ液 $\left(\mathrm{Na}_{2} \mathrm{CO}_{3} 15\right.$ $\%,\left(\mathrm{NaPO}_{3}\right)_{6} 2 \%$ soln.) $5 \mathrm{ml}$ と Folin 試薬 ${ }^{4)} 1 \mathrm{ml}$ を加えよく混和する. 30分静置後 Elma Spectrophotometer M-IV を用い650 m $\mu$ にて比色定量する.

（vi）生菌数の測定 : 食品衛生検査法 ${ }^{5)}$ の標準平板培 養法により測定する.

（vii） ジアゾ反応陽性物質の検出：

a) 検出試料 VBN および遊離チロシンの定量に使 用したのちの残液を濃縮し，ペーパークロマトグラフィ 一検出試料とした。

b）展開掞よび溶媒 東洋口紙 No. $52 ， 2 \times 40 \mathrm{~cm}$ を 用い $10 \%$ アンモニア水飽和ブタノール6) で約 18 時間展開 した。

c）発色液 第 1 液：1\%スルファニルアミド $10 \%$ 塩 酸溶液 $20 \mathrm{ml}$ と $5 \%$ 亜硝酸ナトリウム $20 \mathrm{ml}$ を分液ロー

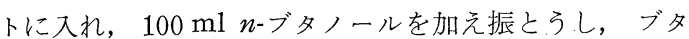
ノール層（ジアゾ試薬）を使用する. 第 2 液 : 半飽和炭 酸ナトリウム液。

展開口紙を乾燥後第 1 液を, 次いで第 2 液を噴霧す る. 乾燥後スポットの色調と Rfを記録する.

\section{III 実験結果および考察}

0.2 Mrads の $\gamma$ 線照射時鷄肉の保存効果に関し前記 7 項目の実験結果を表示し, 対照区と比較検討する(Table $1 \sim 4$, Fig. $2 \sim 4$ ).

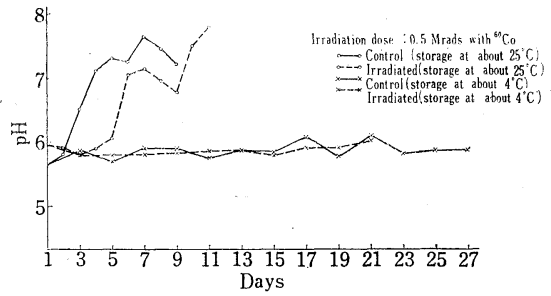

Fig. 2. $\mathrm{pH}$ value of chickens during storage

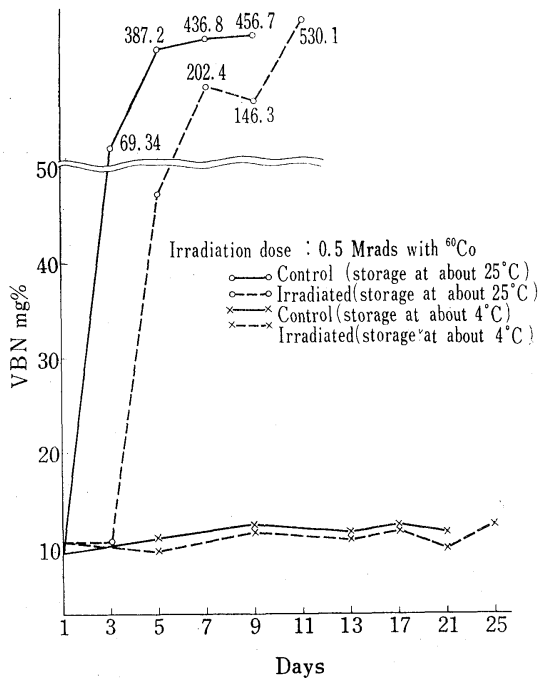

Fig. 3. VBN of chickens during storage

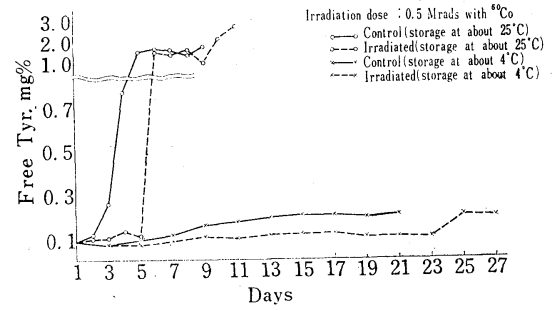

Fig. 4. Free tyrosine of chickens during storage

官能検查 (Table 1)：0.5 Mrads 照射直後における試 料の形状，におい，色調は，いずれも対照区と相違が見 られなかった。

高温保存区 $\left(25 \pm 2^{\circ}\right.$ 保存のもの，以下同じ)では非照射 区に㧍いて，第 3 日に形状に変化をきたし，酸味臭を発 するとともに緑かっ色化し，腐敗の状況を呈した。照射 区では第 3 日に照射臭と思われる異臭および退色を認め 第 5 日には腐敗臭を伴う形状の変化と色調の変化（緑か っ色〜黄かっ色）とを認めた。 
Table 1. Results Obtained on Sensory Test

Irradiation : 0.5 Mrads with ${ }^{60} \mathrm{Co}$

\begin{tabular}{|c|c|c|c|c|c|c|c|}
\hline \multirow{2}{*}{\multicolumn{2}{|c|}{ Storage(days) }} & \multicolumn{2}{|c|}{ Appearance } & \multicolumn{2}{|c|}{ Odor } & \multicolumn{2}{|c|}{ Color } \\
\hline & & control & irradiated & control & irradiated & control & irradiated \\
\hline Storage at about $25^{\circ} \mathrm{C}$ & $\begin{array}{c}1 \\
2 \\
3 \\
4 \\
5 \\
6 \\
7 \\
8 \\
9 \\
10\end{array}$ & $\begin{array}{l}- \\
- \\
\pm \\
+ \\
H \\
H \\
H \\
H \\
H\end{array}$ & $\begin{array}{l}- \\
- \\
- \\
- \\
\pm \\
+ \\
H \\
H \\
H \\
H\end{array}$ & $\begin{array}{l}- \\
- \\
+* 1 \\
H^{* 5} \\
H^{* 6} \\
\text { H' } \\
H \\
\text { H } \\
\text { H }\end{array}$ & $\begin{array}{l}- \\
- \\
\pm * 2 \\
+* 1 \\
H * 5 \\
H \\
H \\
H \\
H \\
H\end{array}$ & $\begin{array}{l}- \\
- \\
\pm^{* 3} \\
+ \\
+ \\
\mathrm{H} \\
\mathrm{H} \\
\mathrm{H} \\
\mathrm{H}\end{array}$ & $\begin{array}{l}- \\
- \\
\pm^{* 4} \\
- \\
+^{* 3} \\
H^{* 7} \\
H \\
H \\
H \\
H\end{array}$ \\
\hline Storage at about $4^{\circ} \mathrm{C}$ & $\begin{array}{c}1 \\
3 \\
5 \\
7 \\
9 \\
11 \\
13 \\
15 \\
17 \\
19 \\
21\end{array}$ & $\begin{array}{l}- \\
- \\
- \\
- \\
- \\
- \\
- \\
- \\
- \\
- \\
\pm\end{array}$ & $\begin{array}{l}- \\
- \\
- \\
- \\
- \\
- \\
- \\
- \\
- \\
- \\
-\end{array}$ & $\begin{array}{l}- \\
- \\
- \\
- \\
- \\
- \\
- \\
- \\
- \\
- \\
-\end{array}$ & $\begin{array}{l}- \\
- \\
- \\
- \\
- \\
- \\
\pm^{* 2} \\
- \\
- \\
- \\
-\end{array}$ & $\begin{array}{l}- \\
- \\
- \\
- \\
- \\
- \\
- \\
- \\
- \\
- \\
-\end{array}$ & $\begin{array}{l}- \\
- \\
- \\
- \\
- \\
- \\
- \\
- \\
- \\
- \\
-\end{array}$ \\
\hline
\end{tabular}

- : Normal \pm : Uncertained change $\quad+$ : Appreciable change

H : Considerable change $\#$ : Severe change

$* 1$ : sour *2: foreign *3: greenish brown $*_{4}^{4}$ : fading *5: uncomfortable

$* 6$ : putrid $* 7$ : yellowish brown

Table 2. Results on RRT of Chickens during Storage

Irradiation: 0.5 Mrads with ${ }^{60} \mathrm{Co}$

\begin{tabular}{|c|c|c|c|c|c|c|c|c|c|c|c|}
\hline \multirow{2}{*}{$\begin{array}{c}\text { Storage } \\
\text { (days) }\end{array}$} & \multirow{2}{*}{ Rample } & \multicolumn{4}{|c|}{ Storage at about $25^{\circ} \mathrm{C}$} & \multirow{2}{*}{$\begin{array}{c}\text { Storage } \\
\text { (days) }\end{array}$} & \multirow{2}{*}{ Sample } & \multicolumn{4}{|c|}{ Storage at about $4^{\circ} \mathrm{C}$} \\
\hline & & $30 \mathrm{~min}$ & 60 & 120 & 180 & & & $30 \mathrm{~min}$ & 60 & 120 & 180 \\
\hline 1 & $\begin{array}{c}\text { control } \\
\text { irradiated }\end{array}$ & $\begin{array}{l}0 \\
0\end{array}$ & $\begin{array}{l}1 \\
0\end{array}$ & $\begin{array}{l}2 \\
1\end{array}$ & $\begin{array}{l}2 \\
1\end{array}$ & 1 & $\begin{array}{c}\text { control } \\
\text { irradiated }\end{array}$ & $\begin{array}{l}0 \\
0\end{array}$ & $\begin{array}{l}1 \\
0\end{array}$ & $\begin{array}{l}2 \\
1\end{array}$ & $\begin{array}{l}2 \\
1\end{array}$ \\
\hline 3 & $\begin{array}{l}\text { control } \\
\text { irradiated }\end{array}$ & $\begin{array}{l}2 \\
1\end{array}$ & $\begin{array}{l}2 \\
1\end{array}$ & $\begin{array}{l}2 \\
1\end{array}$ & $\begin{array}{l}2 \\
2\end{array}$ & 5 & $\begin{array}{l}\text { control } \\
\text { irradiated }\end{array}$ & $\begin{array}{l}0 \\
0\end{array}$ & $\begin{array}{l}1 \\
0\end{array}$ & $\begin{array}{l}2 \\
1\end{array}$ & $\begin{array}{l}2 \\
1\end{array}$ \\
\hline 5 & $\begin{array}{l}\text { control } \\
\text { irradiated }\end{array}$ & $\begin{array}{l}2 \\
1\end{array}$ & $\begin{array}{l}2 \\
2\end{array}$ & $\begin{array}{l}3 \\
2\end{array}$ & $\begin{array}{l}4 \\
2\end{array}$ & 9 & $\begin{array}{c}\text { control } \\
\text { irradiated }\end{array}$ & $\begin{array}{l}0 \\
0\end{array}$ & $\begin{array}{l}1 \\
0\end{array}$ & $\begin{array}{l}1 \\
1\end{array}$ & $\begin{array}{l}2 \\
2\end{array}$ \\
\hline 7 & $\begin{array}{l}\text { control } \\
\text { irradiated }\end{array}$ & $\begin{array}{l}0 \\
0\end{array}$ & $\begin{array}{l}2 \\
1\end{array}$ & $\begin{array}{l}2 \\
2\end{array}$ & $\begin{array}{l}2 \\
2\end{array}$ & 13 & $\begin{array}{c}\text { control } \\
\text { irradiated }\end{array}$ & $\begin{array}{l}0 \\
0\end{array}$ & $\begin{array}{l}0 \\
0\end{array}$ & $\begin{array}{l}1 \\
1\end{array}$ & $\begin{array}{l}2 \\
2\end{array}$ \\
\hline 9 & $\begin{array}{c}\text { control } \\
\text { irradiated }\end{array}$ & $\begin{array}{l}1 \\
0\end{array}$ & $\begin{array}{l}2 \\
1\end{array}$ & $\begin{array}{l}2 \\
2\end{array}$ & $\begin{array}{l}2 \\
2\end{array}$ & 17 & $\begin{array}{l}\text { control } \\
\text { irradiated }\end{array}$ & $\begin{array}{l}0 \\
0\end{array}$ & $\begin{array}{l}0 \\
0\end{array}$ & $\begin{array}{l}1 \\
1\end{array}$ & $\begin{array}{l}2 \\
2\end{array}$ \\
\hline 11 & $\begin{array}{l}\text { control } \\
\text { irradiated }\end{array}$ & 1 & 2 & 2 & 3 & 21 & $\begin{array}{c}\text { control } \\
\text { irradiated }\end{array}$ & $\begin{array}{l}0 \\
0\end{array}$ & $\begin{array}{l}1 \\
1\end{array}$ & $\begin{array}{l}2 \\
2\end{array}$ & $\begin{array}{l}2 \\
2\end{array}$ \\
\hline & $\begin{array}{c}\text { control } \\
\text { irradiated }\end{array}$ & & & & & 25 & $\begin{array}{c}\text { control } \\
\text { irradiated }\end{array}$ & 0 & 1 & 2 & 2 \\
\hline
\end{tabular}

RRT samples are compared with Lactester-A Table (Wakō Pure Chem. Indus. LTD) and when the degree of sample's reduction are equivalent to one of colors in the table, the color number is noted here 
Table 3. Bact. Numbers of Chickens during Storage Irradiation : 0.5 Mrads with ${ }^{60} \mathrm{Co}$

\begin{tabular}{|c|c|c|c|c|c|}
\hline \multirow{2}{*}{$\begin{array}{l}\text { Bact. No. } \\
\text { Storage } \\
\text { (days) }\end{array}$} & \multicolumn{2}{|c|}{ Storage at about $25^{\circ} \mathrm{C}$} & \multicolumn{3}{|c|}{ Bact. No. - Storage at about $4^{\circ} \mathrm{C}$} \\
\hline & control & irradiated & $\begin{array}{l}\text { Storage } \\
\text { (days) }\end{array}$ & control & irradiated \\
\hline 1 & $4,800 * 1$ & $<3,000$ & 1 & 4,800 & $<3,000$ \\
\hline 3 & 22,000 & $<3,000$ & 5 & 7,000 & 8,000 \\
\hline 5 & 3,400 & L. A. $* 2$ & 9 & 4,300 & $<3,000$ \\
\hline 7 & L.A. & $<3,000$ & 13 & 11,000 & $<3,000$ \\
\hline 9 & 30,000 & L. A. & 17 & 5,700 & L. A. \\
\hline 11 & 85,000 & $<3,000$ & 21 & 55,000 & L. A. \\
\hline & & & 25 & & $<3,000$ \\
\hline
\end{tabular}

1 Bact. numbers per gram material

*2 Laboratory Accident

Table 4. Detection of the Diazo-reaction Positive Substances

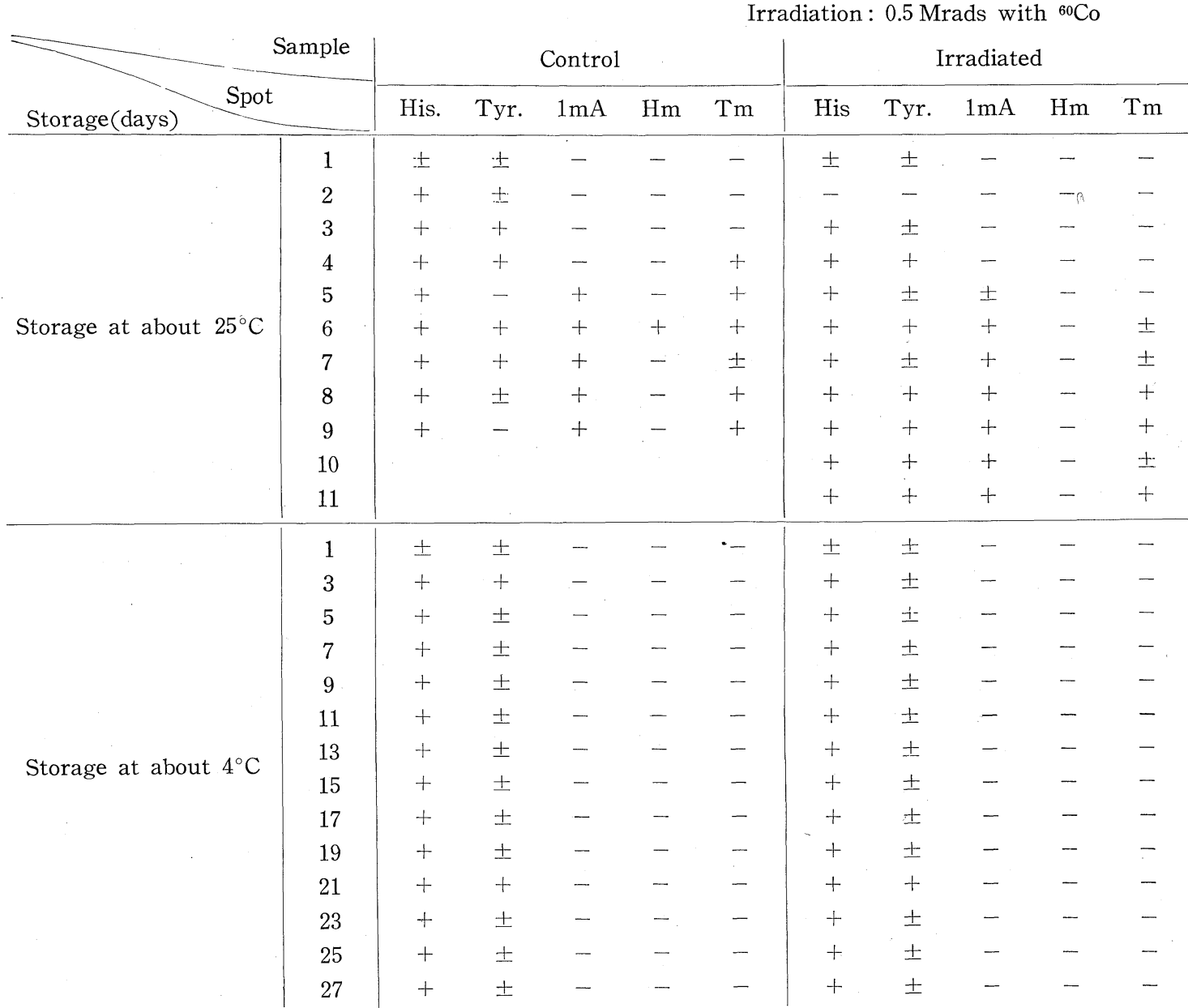

His. : Histidine Tyr.: Tyrosine ImA : Imidazol acetic acid Hm : Histamine Tm : Tyramine Paper chromatography

Solvent : $n$-butanol saturated with $10 \% \mathrm{NH}_{4} \mathrm{OH}-$ not detected \pm uncertain + detected Detection : diazo reaction 
低温保存区 $\left(4 \pm 1^{\circ}\right.$ 保存のもの，以下同じ）では照射 の有無にかかわらず 21 日開当初の弁能所見を維持した。 ただし，例外的に照射区の第13日の試料にやや異臭を発 つものが存在した，15日以後の試料に変化の見られない 点から，この原因は明らかにしえない。

$\mathrm{pH}$ (Fig. 2)：第 1 日の $\mathrm{pH}$ 価は非照射区 $5.85 に$ 対し 照射区5.94とやや高い価を示し, 1.0 Mrads 照射時1) と 逆の結果を示した。一般に食肉の照射は $\mathrm{pH}$ 価の上昇を ஆたらすといわれている7゙。

高温保存区では，非照射区において第3日にすでに $\mathrm{pH} 6.50$ を示し腐敗初期に達する．照射区に拀いては第 $5 \sim 6$ 日にこの段階となる.

低温保存区では，照射の有無は実験期間（21日間）中， $\mathrm{pH}$ 価に影響なく $\mathrm{pH}$ 5.5〜6.1の範囲にとどまった。す なわち, 食肉保存に関し, 低温は0.5 Mrads 照射に匹敵 する因子であることが明らかである.

官能検查と $\mathrm{pH}$ 価測定の結果から, 高温保存の場合, 0.5 Mrads 照射は非照射試料に比べ約 2 日間保存期間を 延長せしめろることが確認された。

RRT(Table 2)：本実験において得られた数值が大と なるに従って, 食品の鮮度は低下する.

第 1 日にして，RRT 30分区を除き，非照射区はいず れも照射区よりもじん速に退色することを認めた。

高温保存区では，非照射区が第 3 日，照射区が第 5 日 において，それぞれの60分，120分測定の絬果から，腐 敗の徵候があらわれた。この 2 日の差は 効果を示すものといえる.

低温保存区では，非照射区と照射区との差は顕著でな い. 前項に論じたごとく，照射效果が低温という内子に マスクされていることを物語っている.

VBN (Fig. 3)：第 1 日において照射区は非照射区に 比べわずかに高い值を示した。

高温保存区では, 非照射区が第 3 月に初期脮敗の段階 と目される量 (30 mg\%) をはるかに越す $69.34 \mathrm{mg} \%$, 照射区が第 5 日 $47.29 \mathrm{mg} \%$ を示した。

低温保存区では，非照射区が常に照射区よりも蓠い值 を示し，VBN が漸增していくことから，低湿において も非照射区が照射区に比べ早く变質することが推察され る.

遊離チロシン(Fig. 4)：照射直後(第1日)に拈いては 非照射，照射区はそれぞれ $0.0825 \mathrm{mg} \% ， \quad 0.0805 \mathrm{mg} \%$ でほとんど差はなかった。

高温保存区では，非照射区㧍よび照射区の遊離チロシ ソ量は，当初は緩慢に，第 4 日および第 6 日に至ってそ れぞれ急激に増加を見る。すなわち， $\gamma$ 線照射は約 2 日 の保存期間を延長させたことになる。

低温保存区では，非照射区は照射区に比べ常に简く絴 日的にわずかながら漸增し，VBN の場合と全く同一の 傾向を示した。
遊離チロシン量と他の测定項目で得られた絬果とを此 較検付した場命, 鹪肉に扔いては $0.2 \sim 0.3 \mathrm{mg} \%$ の遊離 チロシン童が腐敗に入る段階と考えられる.

作淢数 (Table 3)：第 1 日0 $4800 / \mathrm{g}$ の生菌を有する 鵎肉が照射後は $3000 / \mathrm{g}$ 以下となること，高温保存区の 第 3 日，第11日拈よび低温保存区の第 9 日, 第 13 日の生 菌数の測定結果から, 明らかに $\gamma$ 線照射による殺菌に线 来する保存効果の持続が認められた。

ジアゾ反応陽性物質の検出 (Table 4) : イミダゾール 核およびフェノール核を有する遊離のアミノ酸, アミン 類はジアゾ試楽に陽性である。

遊離のヒスチジン，チロシンは 4 群の実験区とも，お おむね保存初期より検出されている.

高温保存区では，非照射区において第 4 日以降チラミ ンが，第 5 日以降イミダゾール酶酸（文献值同定）がそ れぞれ検出された。一方照射区においては第 6 日以降 ミダゾール酶酸, 第 8 日以降チラミンが検出されたが, ヒスタミンは見られなかった。

低温保存区では，ヒスチジンおよびチロシンが検出さ れるにとどまった。

以上の結果から㠔敗の進行に伴いチロシンは脱炭酸さ れてチラミンに，ヒスチジンは酸化的脱アミノされてイ ミダゾール酢酸, あるいは脱炭酸されてヒスタミンに移 行するものと推察されるが確かでない。な拀，ヒスチジ ンの分解については，まず脱炭酸によりヒスタミンとな りその分解の途上でイミダゾール醡酸の生成を就めると の報告8)がなされている.

IV 総 括

鷄胸筋のひき肉に ${ }^{60} \mathrm{Co}$ 線源の $\gamma$ 線を $0.5 \mathrm{Mrads}$ 照射 し嵓温 $\left(25 \pm 2^{\circ}\right)$ と低温 $\left(4 \pm 1^{\circ}\right)$ に区分保存し，その 照射後および短期間保存中の諸变化と保存効果を非照射 肉と比較しながら検副を加えた。

鷄肉に与える 0.5 Mrads 照射はわずかながら $\mathrm{pH}$, VBN, 牛藏数, 遊離チロシン等の偵に影響を及ぼした。 すなわち $\mathrm{pH}, \mathrm{VBN}$ は照射区が非照射区に比べ高く, 生菻数, 遊離チロシンでは照射区のうが低い值を示し た。一方官能検查， RRT，ジァゾ反応陽性物質の検出 等では照射それ自体（第1日の絬果）の影響は差として 明らかでない。

保存期間中では，高温区で照射の影響は経日的にはっ きりする，すなわち官能検查， $\mathrm{pH} ， \mathrm{RRT}, \mathrm{VBN}$ ，生菌 数, 遊離チロシン等では非照射区は第 3 日にすでに履敗 を示すに対し，照射区はいずれもの結果から第 5 日頃に 閤敗に入った。

低温保存中では，官能検查， pH，RRT，ジアゾ反応陽 性物質検出等では照射の影響は判然としないが，VBN， 生菌数, 遊離チロシンでは明らかに低温ながらも照射の 保存効果が見られ， $r$ 線照射が肉の内部变化を抑制して いることが認められた。 
要するに0.5 Mrads 照射の高温保存鶏肉は非照射区 に比べてほぼ 2 日ほどの保存効果をあらわすがその効果 は $1.0 \mathrm{Mrad}$ 時の約 $1 / 3$ である. 低温保存では照射は内 部の変質をきたさずに保存が可能であることを確䞏し た.

なお，鮮度判定法として遊離チロシソの定量は効果的 で鶏肉の場合 $0.25 〜 0.3 \mathrm{mg} \%$ の線を越えるときが一応 腐敗の目安となりうると推察される。またチラミン, イ ミダゾール酢酸等の生成は简敗に入ってから検出される ことが明らかとなった。

本実験を行なうに当り試料の照射にご協力を賜わった 都立アイソトープ総合研究所の岡 充, 山崎邦郎の両氏 に感謝の意を表します。

この報文の要旨は日本食品衛生学会第 9 回学術講演会 （昭和 40 年 5 月，大阪市）において発表.

文献

1）木崎卓平, 神谷 誠：明大農研報. 18, 1(1965).
2）乳業技術講座編集委員会: “牛乳・乳製品検査” p. 221（1963）朝倉書闾.

3）厚生省編：“食品衛生検查指針 I” p. 1 13 (1959)；石坂音治：“微量昖散分析提要” p. 62 （1951）柴田化学器械工業 k k .

4) O. Folin, V. J. Ciocaltee: J. Biol. Chem. 73, 627 (1927).

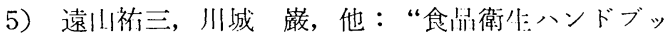
ク” p. 93 (1957) 朝倉舅店。

6）佐竹一夫：“クロマトグラフィー” p. 99（1955） 共立出版.

7) American Meat Institute Foundation: "The Science of Meat \& Meat Products" p. 305 (1960) Reinhold; F. Batzer et al.: J. Agr. Food Chem. 3, 64 (1955).

8）佐竹一夫, 林 誠, 他：腐研報. 5, 79 (1952). 